\title{
A stakeholder perspective on the implementation of sustainable construction practices.
}

MASHWAMA, N.X., THWALA, D., AIGBAVBOA, C. and HAMMA-ADAMA, $M$. 


\title{
A STAKEHOLDER PERSPECTIVE ON THE IMPLEMENTATION OF SUSTAINABLE CONSTRUCTION PRACTICES
}

\author{
NOKULUNGA XOLILE MASHWAMA ${ }^{1}$, DIDIBHUKU THWALA², CLINTON \\ AIGBAVBOA $^{1}$, and MANSUR HAMMA-ADAMA ${ }^{3}$ \\ ${ }^{1}$ Dept of Construction Management and Quantity Surveying, University of Johannesburg, \\ Johannesburg, South Africa \\ ${ }^{2}$ SARChI in Sustainable Construction Management and Leadership in the Built Environment, \\ Faculty of Engineering and the Built Environment, University of Johannesburg, \\ Johannesburg, South Africa \\ ${ }^{3}$ Scott Sutherland School of Architecture and Built Environment, Robert Gordon University \\ Aberdeen, United Kingdom
}

\begin{abstract}
The South African construction industry accounts for $23 \%$ of the greenhouse emissions, while manufactured materials amount to $4 \%$ of carbon dioxide emission. The human emission of greenhouse gases is the reason why the earth is warming up and making climate change a serious problem. The study adopted a quantitative approach in order to investigate on a stakeholder's perspective on level of implementation and awareness of Sustainable Construction Practices (SCPS). A structured survey questionnaire was used as a tool for data collection where the questionnaires were distributed to construction industry stakeholders. Out of the 75 distributed questionnaires, 60 were retrieved and all were valid and usable. The study revealed that sustainable construction practices is partially implemented and the responded are aware of Industrialization building system; construction ecology; life cycle costing; design for the environment; lean construction as the best construction practices that when fully adopted they would contribute greatly to the ecosystem we live in. This study contributes to a wider awareness of SCPs to the professional in the industry.
\end{abstract}

Keywords: Lifecycle costing, Sustainability, Construction ecology, Lean construction.

\section{SUSTAINABILITY}

Sustainability is a global problem, with the depletion of natural resources. The South African government is been challenged to mitigate this issue by using sustainable construction principles (Aigbavboa et al. 2017). Sustainability governs decisions concerning building material; and also refers to guidance on the three features of economic, environmental and social wellbeing (Sinha et al. 2014). The sustainability targets to preserve raw materials, the economy of water and energy utilization, and putting preventive measures against effects on the environment due to the development of the infrastructures (Windapo and Gouding 2014). Another aim of sustainability is the zero-impact building which cleans its own polluted water, the building produces the energy it needs, waste that is created is recycled (Sinha et al. 2014). Kibert (2012) stated that in order for 
a building to be sustainable and green, environmentally friendly principles must be used during construction while promoting efficiency and it must have a robust design.

\section{SUSTAINABLE CONSTRUCTION PRACTICES}

According to Mashwama et al. (2019), sustainable practice (SC) is to deliver the construction projects at a reasonable economic stand while preserving natural resources including the social wellbeing of the occupants. Azis et al. (2012) stated that SC involves a commitment to: economic stability - the efficient use of energy, materials, water, labor and resources; Environmental Stability - using resources efficiently while protecting the environment; and Social stability - making sure that occupants get satisfactory results. Thus, Al-Sanad (2015) summarizes the concept of SC; he describes SC as meeting the contemporary needs without compromising the requirements for future generations. Decisions on the type of materials and how these materials are generated (Kádárová et al. 2015) are some of the concerning issues, which were raised by the SC; the environmentally friendly building is the goal of the SC. The following briefly described the concepts and technologies of SC that have functions to achieving sustainability and yielding acceptable results at the construction and post-construction stages.

Nanotechnology: This technology offers a wide variety of options that can help in the development of new materials with multiple functionalities. Furthermore, it covers the design, construction and utilization of functional structures that are measured in nanometers (Ametepey and Aigbavboa 2014).

Ecological Footprint: This concept is capable of analyzing all stages of materials production, and urban development to every activity of organizations. Ecological Footprint considers the land including human activities, ecosystems and the land area available to be used for agricultural purposes (Cole 2000).

Industrialization Building Systems (IBS): This system of construction deploys a technique of manufacturing building components in a controlled environment, whether on-site or off-site. These building components are of transportation size, thus, transported, positioned and assembled into a structure with a minimal additional site works (Cole 2000). IBS contribute to increased project delivery, waste reduction and cost savings (Kamar et al. 2009).

Life cycle assessment ( $L C A)$ : The main objective of LCA is to satisfy the customers' need while achieving the equilibrium between the product and the environment (Marques and Loureiro 2013). LCA is used to identify engineering solutions that will aid in the goal of sustainable construction during product development processes, which green markets focused (Kádárová et al. 2015). LCA must be incorporated from the initial planning design, to ensure strategic planning and to see which innovative opportunity can be explore for a successful project while considering the sustainable construction principles and meeting the needs of the customer with minimal impacts on the environment.

Building information modeling (BIM): BIM is an innovative process that brings collaborative working, encourages off-site production thereby minimizing waste (Hamma-Adama and Kouider 2018). BIM is a process that is enabled by technologies; it is a digital documentation of building planning, design, construction and successive operation (Tauriainen et al. 2016).

Design for the environment (DfE): The DfE is a systematic consideration of design performance concerning safety, health and the environmental objectives considering the entire production process and product life cycle (Cole 2000). Furthermore, the properties of DfE are to: reduce the energy needed for manufacturing products; reduce the amount of material used; and drive the development of materials that have less impact on the environment (Marques and Loureiro 2013). 
Life cycle costing ( $L C C)$ : LCC enables strategic cost management of the whole construction period until demolition (Reddy 2016). Therefore, LCC is used to compare design options on the basis of asset whole life cost with the objective of providing value for money (Kádárová et al. 2015).

Ecological economics: The goal of ecological economics is to understand the connection between the human and the natural systems in-order to develop effective policies that can be used to protect resources and to ensure that they are distributed fairly (Nahman et al. 2009).

Construction ecology: This refers to the international movement that is commonly called "green building" (Kibert 2012). The construction ecology addresses pollution, waste management, water management, recycling, reusing, and most importantly energy efficiency: thus, it is recognized as a way to mitigate all the negative impacts accruing (Windapo 2014).

Biomimicry: The biomimicry imitates the nature's best designs and processes in order to solve human problems, it mimics the designs of the organisms that have evolved and also provides solutions for energy supply, waste management systems, and the structural efficiency (Mirniazmandan and Rahimianzarif 2017).

Lean construction: The lean construction eliminates waste from construction processes while maximizing productivity and project transparency (Tauriainen et al. 2016).

Value management $(V M)$ : This is a service rendered on a project from the design stage, which targets to maximize the functional and economic values through comparison and audit of all decisions against the project value to the client or customer. The VM theories are recommended to be used during the key stages of a project so that resources can be used more efficiently, and wastage be minimized as much as possible (Al-Sanad 2015).

\section{RESEARCH METHOD}

This study adopted a quantitative method to explore a stakeholders' standpoint on the level of implementation and awareness of SCPs. Seventy-five questionnaires were distributed, targeted the Mpumalanga Province, the Republic of South Africa. Sixty questionnaires were retrieved and all valid for analysis. The completed surveys are from construction professionals who are project managers, quantity surveyors, engineers and contractors all registered to the Construction Industry Development Board (CIDB). Two methods were used in delivering the survey questionnaires, via email and hand (hard copy) distribution during contractors-consultants site meetings. A five-Point Linkert scale measurement was used to provide a wide range of possible scores while maintaining the statistical analysis options. Two different measurements are used; firstly, 1 to 5 for "Strongly Disagree" (SD) to "Strongly Agree" (SA). Secondly, 1 to 5 for "Extremely Unlikely" (EU) to "Extremely Likely" (EL). Finally, the five-point scales were transformed to Mean Item Score (MIS).

\subsection{Computation of the Mean Item Score (MIS)}

The MIS was carried out using the total from all weighted responses concerning the total reactions (answers) on a particular aspect. The MIS is used in ranking factors under consideration. The MIS has a mathematical expression on each item base the following relationship by Eq. (1):

$$
\text { MIS }=\quad \underline{1 n}_{1}+2 n_{2}+3 n_{3}+4 n_{4}+5 n_{5}
$$

where: 
$\mathrm{n}_{1}=$ number of respondents for strongly disagree; $\mathrm{n}_{2}=$ number of respondents for disagree;

$\mathrm{n}_{3}=$ number of respondents for neutral; $\mathrm{n}_{4}=$ number of respondents for agree; $\mathrm{n}_{5}=$ number of respondents for strongly agree; and $\mathrm{N}=$ total number of respondents

\section{FINDINGS AND DISCUSSIONS}

\subsection{Level of Implementation of Sustainable Construction Practices}

Forty-two per cent of the respondents are with the opinion that the implementation of SCP is within a lower level $(0-25 \%)$. 25\% of the respondents believed that it is practiced between 25$50 \%, 18 \%$ went with the range of $50-75 \%$, and $15 \%$ in the range of $75-100 \%$. Figure 1 below presents a graphical summary of the result.

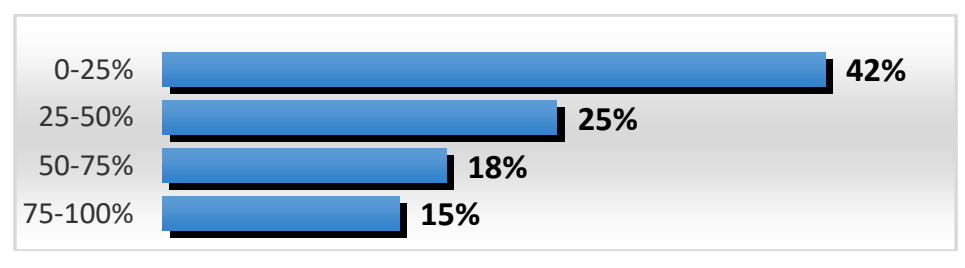

Figure 1. Level of implementation of SCP.

\subsection{Respondent's Awareness to Sustainable Construction Practices in the South African Construction Industry}

The respondents were asked to rate their level of awareness of sustainable construction practices in the construction industry. According to their responses, the Industrialization building system was ranked first with MIS=3.89 \& STD of 0.982; Construction Ecology ranked second with MIS=3.82 \& STD=1.118; followed by Lean construction as third, Design for the environment, fourth; Ecological footprint, fifth; Life cycle costing ranked sixth; Value management ranked seventh; Building Information Modeling, eighth; Life cycle assessment ranked ninth; Ecological Economics ranked tenth; Biomimicry ranked eleventh, and lastly Nanotechnology was ranked twelfth with MIS=2.22 \& STD=1.010.

Table 1. Awareness of SCP in the South African construction industry.

\begin{tabular}{lccc}
\hline Sustainable construction practices & Mean & STD & R \\
\hline Industrialization Building systems & 3.89 & 0.982 & 1 \\
Construction Ecology & 3.82 & 1.118 & 2 \\
Lean construction & 3.80 & 1.066 & 3 \\
Design for the environment & 3.78 & 0.893 & 4 \\
Ecological footprint & 3.71 & 1.098 & 5 \\
Life cycle costing & 3.67 & 1.110 & 6 \\
Value management & 3.64 & 0.893 & 7 \\
Building Information Modeling & 3.60 & 1.066 & 8 \\
Life cycle assessment & 3.41 & 1.150 & 9 \\
Ecological Economics & 3.02 & 1.078 & 10 \\
Biomimicry & 2.56 & 1.207 & 11 \\
Nanotechnology & 2.22 & 1.010 & 12 \\
\hline
\end{tabular}




\subsection{Respondents' Most Preferred Sustainable Construction Practices in the South African Construction Industry}

According to the respondents, their most preferred sustainable construction practices were ranked as follows: Lean construction and Industrialization building system are ranked number one with (MIS=3.99; STD=0.856 \& STD=0.956) respectively; ranked second was Construction Ecology with MIS=3.65 \& STD=1.235; Life cycle costing and Value management were ranked third with MIS=3.63; Building Information Modeling ranked fourth with MIS=3.51 \& STD of 0.998; Life cycle assessment was ranked fifth, Ecological Economics was ranked sixth, Design for the environment was ranked seventh, Ecological footprint ranked eighth, and Biomimicry and Nanotechnology were ranked the last with MIS of $2.96 \&$ STD $=0.985 \& 1.108$ respectively.

Table 2. Most preferred SCP.

\begin{tabular}{lccc}
\hline Most preferred SCP & Mean & STD & R \\
\hline Lean construction & 3.99 & 0.856 & 1 \\
Industrialization Building systems & 3.99 & 0.956 & 1 \\
Construction Ecology & 3.65 & 1.235 & 2 \\
Life cycle costing & 3.63 & 1.125 & 3 \\
Value management & 3.63 & 0.847 & 3 \\
Building Information Modeling & 3.51 & 0.998 & 4 \\
Life cycle assessment & 3.46 & 1.023 & 5 \\
Ecological Economics & 3.34 & 0.958 & 6 \\
Design for the environment & 3.06 & 1.087 & 7 \\
Ecological footprint & 2.98 & 1.056 & 8 \\
Biomimicry & 2.96 & 0.985 & 9 \\
Nanotechnology & 2.96 & 1.108 & 9 \\
\hline
\end{tabular}

\section{CONCLUSION}

The rapid growth of construction activities has benefited the communities in a great way with the development of infrastructure and the growth of the economy, which also contributes to the pollution due construction waste and the adverse impacts on the environment. The study revealed that the sustainable construction practices are partially implemented by the construction stakeholders, $42 \%$ Construction stakeholders believe that SCP is practiced between $0-25 \%$ and $18 \%$ believed it was practiced between $75 \%-100 \%$. The huge difference shows how poor SCP implementation is. Furthermore, the stakeholders are aware of SCPs such as Industrialization building systems, construction ecology, lean construction, and design for the environment. Majority of the stakeholders believed that lean construction, industrialization building systems, construction ecology, life cycle costing are the most preferred SCPs to be adopted; so that the environment, government, and occupants could benefit. Therefore, the adoption and implementation of these building practices could yield a strong business benefits and increase inter-firms' competition. The sustainable construction practices do not only reduce impacts on the environment and improve sustainability, but they also decrease operational costs and increase productivity. It has been established that, sustainable construction has an effect on the employee wellbeing. There is low level of awareness; thus, the stakeholders' awareness through training and workshops is recommended. Government should also provide incentives such as tax cut to those companies implementing the SCP. 


\section{References}

Aigbavboa, C., Oke, A., and Edward, L., Improving Sustainable Construction Practices Through Facility Management, Sustainable Civil Infrastructures, 30-39, 2017.

Al-Sanad, S., Awareness, Drivers, Actions, and Barriers of Sustainable Construction in Kuwait. International Conference on Sustainable Design, Engineering and Construction, Procedia Engineering, 118, 969-983, 2015.

Ametepey, S. O., and Aigbavboa, C., Practitioners Perspectives for The Implementation of Sustainable Construction in Ghana, Proceedings of the DII-2014 Conference, 2014.

Azis, A., Memon, A., Rahman, I., Nagapan, S., and Latif, Q., Challenges Faced by Construction Industry in Accomplishing Sustainability Goals, IEEE Symposium on Business, Engineering and Industrial Applications, 2012.

Cole, R. J., Building Environmental Assessment Methods: Assessing Construction Practices, Construction Management and Economics, 18, 949-957, 2000.

Hamma-Adama, M., and Kouider, T., A Review on Building Information Modelling in Nigeria and Its Potentials, International Journal of Civil, Environmental, Structural, Construction and Architectural Engineering [online], 12(11), 1113-1119, 2018.

Kádárová, J., Kobulnický, J., and Teplicka, K., Product Life Cycle Costing, Applied Mechanics and Materials, 816, 547-554, 2015.

Kamar, K. A. M., Alshawi, M., and Hamid, Z. A., Barriers to Industrialised Building Systems: The Case of Malaysia, Proceedings in BuHu 9th International Postgraduate Research Conference (IPGRC 2009), The University of Salford, Salford, United Kingdom, 2009.

Kibert, C. J., Sustainable Construction: Green Building Design and Delivery, 3rd ed., John Wiley and Sons, Hoboken, NJ, 2012.

Marques, B., and Loureiro, C., Sustainable Architecture: Practices and Methods to Achieve Sustainability in Construction, International Journal of Engineering and Technology, 223-226, April, 2013.

Mashwama, X. N, Thwala, D. W., and Aigbavboa, C. O., Obstacles of Sustainable Construction Project Management in South Africa Construction Industry, Seeds International Conference, September 11-12, 2019.

Mirniazmandan, S., and Rahimianzarif, E., Biomimicry an Approach toward Sustainability of High-Rise Buildings, Journal of Architectural Engineering Technology, 06(02), 1000203, December, 2017.

Nahman, R., Wise, R., and De Lange, W., Environmental and Resources Economics in South Africa; Status Quo and Lessons for Developing Countries, South African Journal of Science, 105, 351-355, 2009.

Reddy, V., Sustainable Construction: Analysis of Its Costs and Financial Benefits, International Journal of Innovative Research in Engineering and Management, 3(6), 522-525, 2016.

Sinha, A. Gupta, R., and Kutnar, A., Sustainable Development and Green Building, Drvna Industrija, 64(1), 45-53, 2014.

Tauriainen, M., Marttinen, P., Dave, B., and Koskela, L., The Effects of BIM and Lean Construction on Design Management Practices, Procedia Engineering, 164, 567-574, 2016.

Windapo, A., and Gouding, J., Understanding the gap between green building practices building and legislation requirements in South Africa, Green Building Practices, 4(1), 67-69, 2014.

Windapo, A., Examination of Green Building Drivers in the South African Construction Industry: Economics versus Ecology, Sustainability, 6, 6088-6106, 2014. 